\title{
Sugars, acids and polyphenols profile of commercial and traditional apple cultivars for processing
}

\author{
Asima AKAGIĆ ${ }^{1,2}{ }^{2}$, Amila VRANAC ${ }^{1}$, Fuad GAŠI ${ }^{1}$, Pakeza DRKENDA ${ }^{1}$, Nermina SPAHO ${ }^{1}$, Sanja \\ ORUČEVIĆ ŽULJEVIĆ ${ }^{1}$, Mirsad KURTOVIĆ ${ }^{1}$, Osman MUSIĆ ${ }^{1}$, Senad MURTIĆ ${ }^{1}$, Metka HUDINA ${ }^{3}$
}

Received April 02, 2019; accepted April 30, 2019.

Delo je prispelo 02. aprila 2019, sprejeto 30. aprila 2019.

\begin{abstract}
Sugars, acids and polyphenols profile of commercial and traditional apple cultivars for processing

Abstract: Three commercial apple cultivars ('Jonagold', 'Granny Smith' and 'Idared') and the local apple cultivar ('Prijedorska Zelenika') from Bosnia and Herzegovina were analysed by HPLC-MS for the content of phenolic compounds in peel and pulp as well content of individual sugars and organic acids. Catechin, (-)-epicatechin, chlorogenic acid, caffeic acid, quercetin 3-O-xyloside, quercetin 3-O-arabinoside, quercetin 3-O-rhamnoside, quercetin 3-O-rutinoside, quercetin 3-Ogalactoside and quercetin 3-O-glucoside were identified in apple peel and (-)-epicatechin, chlorogenic acid and caffeic acid in apple pulp at all observed cultivars. The total sugars content of analysed apple cultivars ranged between 91.61 and $105.45 \mathrm{~g} \mathrm{~kg}^{-1} \mathrm{FM}$, while the total organic acids content was from 5.70 to $15.05 \mathrm{~g} \mathrm{~kg}^{-1} \mathrm{FM}$. The levels of total organic acids and sugars, glucoce/fructose ratio and sugar/acid ratio were affected by cultivars. The mean content of total phenolic compounds was between 427.92 and $1457.95 \mathrm{mg} \mathrm{kg}^{-1} \mathrm{FM}$ in peel and from 113.58 to $439.83 \mathrm{mg} \mathrm{kg}^{-1} \mathrm{FM}$ in pulp and depending upon the cultivars. The presented data clearly demonstrated that traditional apple cultivar ('Prijedorska Zelenika') had significantly higher individual phenolic compounds in pulp in comparison to the commercial cultivars, i.e., 'Idared,' 'Jonagold' and 'Granny Smith' and with respect of that 'Prijedorska Zelenika' is recommended as raw material for cloudy juice processing.
\end{abstract}

Key words: local apple cultivars; commercial apple cultivars; primary metabolites; phenolics; HPLC-MS
Profil slakorjev, kislin in polifenolov komercialnih in lokalnih sort jabolk za predelavo

Izvleček: Pri treh komercialnih sortah jabolk: 'Jonagold', 'Granny Smith' in 'Idared', ter lokalni sorti jabolk 'Prijedorska Zelenika' iz Bosne in Hercegovine smo analizirali s HPLC-MS vsebnost fenolnih spojin v olupku in mesu ter vsebnost posameznih sladkorjev in organskih kislin. Katehin, (-)-epikatehin, klorogenska kislina, kavna kislina, kvercetin-3-ksilozid, kvercetin-3-arabinozid, kvercetin-3-ramnozid, kvercetin-3-rutinozid, kvercetin-3-galaktozid in kvercetin-3-glukozid so bili določeni $\mathrm{v}$ olupku jabolk in (-)-epikatehin, klorogenska kislina in kavina kislina v mesu jabolk pri vseh sortah v poskusu. Vsebnost skupnih sladkorjev je bila v analiziranih sortah jabolk med 91,61 in $105,45 \mathrm{~g} \mathrm{~kg}^{-1}$ sveže mase, skupna vsebnost organskih kislin pa od 5,70 do $15,05 \mathrm{~g} \mathrm{~kg}^{-1}$ sveže mase. Sorte so vplivale na vsebnost skupnih organskih kislin in skupnih sladkorjev, razmerje glukoza/fruktoza in razmerje sladkorji/kisline. Povprečna vsebnost fenolnih spojin je bila med 427,92 in 1457,95 kg kg-1 sveže mase v olupku in od 113,58 do 439,83 $\mathrm{mg} \mathrm{kg}^{-1}$ sveže mase v mesu, kar je bilo odvisno od sorte. Predstavljeni podatki kažejo, da je imela tradicionalna sorta jabolk 'Prijedorska Zelenika' bistveno večje vsebnosti posameznih fenolnih spojin $\mathrm{v}$ mesu v primerjavi s komercialnimi sortami, kot so 'Idared', 'Jonagold' in 'Granny Smith', in zato se sorto 'Prijedorska Zelenika' priporoča kot surovino za predelavo v motni sok.

Ključne besede: lokalne sorte jabolk; komercialne sorte jabolk; primarni metaboliti; fenoli; HPLC-MS

1 Universityof Sarajevo, Faculty of Agricultural and Food Sciences, Sarajevo, Bosnia and Herzegovina

2 Corresponding author, e-mail: a.akagic@ppf.unsa.ba

3 University of Ljubljana, Biotechnical Faculty, Department of Agronomy, Ljubljana, Slovenia 


\section{INTRODUCTION}

Apples and processed apple products contain different amounts of dietary fibres, sugars, acids and various bioactive secondary metabolites, like phenolic compounds, which are responsible for most of the antioxidant activities of the fruit (Hertog et al., 1993; Eberhardt et al., 2000; Boyer and Liu, 2004; Wu et al., 2007; Hyson, 2011; Kschonsek et al., 2018). These classes of substances are characterised by health-promoting effects e.g. reducing the risk of diseases, such as cardiovascular diseases and some forms of cancer (Serra et al., 2012; Sharma, 2014; Gutiérrez-Grijalva et al., 2016, Lin et al., 2016; Bhuyan and Basu, 2017). On the other hand, results of same researchers (Alberto et al., 2006; Jelodarian et al., 2013) demonstrate a direct relationship between the phenolic content of the fruit extracts and antimicrobial effect. Along with sugars and organic acids (Begić-Akagić et al., 2014), phenolics determine the quality of the apples (Nogueira et al., 2006). The polyphenol concentration of apples depends strongly among of all on the cultivar (Perez-Ilzarbe et al., 1991; Tsao et al., 2003; Vieira et al., 2009; Carbone et al., 2011, Vranac et al., 2014), production system (Róth et al., 2005; Veberič et al., 2005; Hecke et al., 2006; Valavanidis et al., 2009; Mikulič Petkovšek et al., 2010) and part of fruits (Drogoudi et al., 2008; Lata et al., 2009; Vieira et al., 2011; Boudabous et al., 2015). Apples contain a variety of phenolic compounds that can be classified into several sub-classes with procyanidins being the most abundant class followed by hydroxycinnamic acids, dihydrochalcones, flavonols, anthocyanins and flavan-3-ols (Alonso-Salces et al., 2004). When selecting cultivars for juice production, special attention is paid to the polyphenols profile and content since they contribute to colour, bitternes and astringency, which provide the "overall mouth-feel" of juice. On the other hand, some polyphenols play an important role in browning characteristics of apple juice. Chlorogenic acid was found as the most important substrate of polyphenol oxidase (PPO). In the presence of oxygen and $\mathrm{PPO}$, chlorogenic acid rapidly oxidises to ortho-quinones, which in turn polymerize quickly to brown or black pigments such as melanin. In addition, procyanidins by the action of the enzyme PPO are involved in enzymatic browning and particularly their degree of polymerization is responsible for cider bitterness and astringency of apple juices (Nicolas et al., 1994). The degree of browning of apples was found to be dependent on the relationship of hydroxycinnamic acids/ procyanidins (Amiot et al., 1992).

According to Kschonsek et al. (2018) in recent decades, new apple cultivars, such as 'Braeburn', 'Elstar', 'Golden Delicious', 'Granny Smith' and 'Jonagold', have become more popular among consumers in Western Eu- rope, resulting in a gradual decrease of cultivation of old cultivars. Generally, new apple cultivars have a lower content of polyphenols (Vrhovšek et al., 2004; Boudabous et al., 2015) because of breeding due to the astringent taste and rapid enzymatic browning. Traditional apple cultivars in Bosnia and Herzegovina are valuable sources of desirable genetic characteristics including important pomological, nutritional and technological characteristics of the fruits (Begić-Akagić et al., 2006). Those cultivars have high phenol content according to Begić-Akagić et al. (2011). Traditional apple cultivar 'Paradija' contained the highest content of phenols (1.003 $\left.\mathrm{g} \mathrm{GAE}^{-1}\right)$, while actual apple cultivar 'Topaz' had the lowest content (0.596 $\left.\mathrm{g} \mathrm{GAE}^{-1}\right)$ during the storage time. Traditional cultivars, exhibit higher natural resistance to pests and diseases, so we hypothesized that the fruits of those cultivars have higher contents of phenolic compounds in the peel and pulp and also contents of organic acid and sugar compared with commercial ones.

Therefore the aim of the present study was i) to scan the sugar and organic acid content of traditional and commercial apple cultivars ii) to select apple cultivars the most appropriate for juice processing according to sugar/ acid ratio iii) to scan individual phenolic composition of the apple pulp and peel of different cultivars, commercial and traditional ones.

\section{MATERIALS AND METHODS}

\subsection{FRUIT MATERIAL}

The study was conducted on 10-yr-old apple trees on 'MM 106' rootstock, growing on sandy loam soil and trained as spindle bush at a commercial orchard in Goražde (Bosnia and Herzegovina). The orchard is planted on the elevation of $335 \mathrm{~m}\left(43^{\circ} 39^{\prime} 33,61^{\prime \prime} \mathrm{N} \mathrm{i}\right.$ $\left.18^{\circ} 58^{\prime} 54,34^{\prime \prime} \mathrm{E}\right)$. Ten trees per apple cultivar were selected according to similar crop load. The trees were spaced at $3.8 \times 1.4 \mathrm{~m}$. The technology of fruit production in the orchards was integrated (IPM- integrated pest management). In the experiment were included commercial apple cultivars 'Idared', 'Jonagold' and 'Granny Smith' as well as autochthonous apple cultivar 'Prijedorska Zelenika'. Fruit sampling was performed at technological maturity, which was determined using the starch iodine test. Fruits from all apple cultivars were picked at one time, from the outer layer of the trees, avoiding the tops and bottoms. Sugars and organic acids were analysed in whole fruit while phenolic compounds in the pulp and peel of the apples separately. For every cultivar five replications were done $(n=5)$, each repetition including 15 
apples sampled from five tree. For the phenolic analysis, the peel was separated from the pulp using ceramic slicers to a $1 \mathrm{~mm}$ cutting depth. Both, the peel and pulp were stored at $-20{ }^{\circ} \mathrm{C}$ until preparation of the samples.

\subsection{STANDARDS AND CHEMICALS}

For the quantification of the organic acids (citric, fumaric and shikimic acids), as well individual sugars (fructose, sucrose, glucose and sorbitol) were used standards acquired from Fluka (Buchs, Switzerland). Malic acid was obtained from Merck (Darmstadt, Germany). The following standards were used for quantification of individual polyphenolic compounds: chlorogenic acid (5-caffeoylquinic acid) and (-)-epicatechin from Sigma (St. Louis, MO, USA), (+)-catechin from Roth (Karlsruhe, Germany), quercetin 3-O-rhamnoside, quercetin 3-Oglucoside, quercetin 3-O-galactoside, quercetin 3-O-xyloside from Fluka (Buchs, Switzerland), and caffeic acid, quercetin 3-O-rutinoside, quercetin 3-O-arabinoside and BHT from Sigma (St. Louis, MO, USA). Methanol was purchased from Riedel-de Haën (Seelze, Germany) and acetonitrile from Sigma-Aldrich (Steinheim, Germany); both were of HPLC grade. Water was bidistilled using Milli-Q system (Millipore, MA, USA).

\subsection{SUGARS AND ORGANIC ACIDS EXTRAC- TION AND ANALYSIS}

For the analysis of individual sugars, organic acids and phenolic compounds in fresh fruit the samples were transferred on dry ice to the laboratory of Chair for Fruit Growing, Viticulture and Vegetable Growing of Department of Agronomy at the Biotechnical Faculty, Ljubljana, Slovenia.

Ten grams of each sample were brought to $40 \mathrm{ml}$ of total volume with bidistilled water and homogenized for one min at $24{ }^{\circ} \mathrm{C}$ with a T-25 Ultra-Turrax (IKA Labortechnik, Staufen, Germany). Samples were left to extract for half an hour at $24{ }^{\circ} \mathrm{C}$ and centrifuged at $10,000 \mathrm{rpm}$ for $7 \mathrm{~min}$ at $5{ }^{\circ} \mathrm{C}$ (Eppendort $5810 \mathrm{R}$ Centrifuge, Hamburg, Germany). The supernatant was used for analysis after filtration through a $0.45 \mu \mathrm{m}$ cellulose filter (Macherey - Nagel, Düren, Germany) into vials.

The Thermo Separation Products HPLC system (Riviera Beach, FL; Pump model P1000; auto sampler model AS1000) was used for the analysis of individual sugar content (sucrose, glucose, fructose and sorbitol) and individual organic acid content (malic, citric, shikimic and fumaric acids). The separation of sugars was carried out using a Rezex RCM -monosaccharide col- umn $(300 \times 7.8 \mathrm{~mm})($ Phenomenex, USA). The mobile phase was bidistilled water, and a refractive index (RI) detector was used for monitoring the eluted carbohydrates according to Hudina and Štampar (2006). Organic acids were analysed using the Razex ROA-Organic Acid $\mathrm{H}+(300 \times 7.8 \mathrm{~mm}$; BioRad, USA) column with particle size $8 \mu \mathrm{m}$ and with the temperature maintained at $65^{\circ} \mathrm{C}$ at a flow rate of $0.6 \mathrm{ml} \mathrm{min}^{-1}$ as described by Hudina and Štampar (2006). Injection volume was $20 \mu \mathrm{l}$. An UV detector was used with a wavelength set at $210 \mathrm{~nm}$. For the mobile phase, $4 \mathrm{mM}$ sulphuric acid was used.

The content of individual organic acids levels (malic, citric, shikimic and fumaric acid) as well sugars (sucrose, fructose, glucose and sorbitol) were expressed in $\mathrm{g} \mathrm{kg}^{-1}$ of FM. Total acids and sugars were calculated as the sum of individual acids as well sugars. Values of total sugar content and total organic acid content were used to calculate the sugar/organic acid ratio.

\subsection{INDIVIDUAL PHENOLIC COMPOUNDS EX- TRACTION AND ANALYSIS}

Five independent extractions were carried out using $10 \mathrm{~g}$ (FM) of pulp or $5 \mathrm{~g}$ of peel, which were homogenized with a $10 \mathrm{ml}$ extraction solution (methanol containing $3 \%$ formic acid and $1 \%$ of 2.6-di-tert-butyl4-methylphenol (BHT) to prevent degradation of the phenolic compounds) in an ultrasonic ice bath for $1 \mathrm{~h}$ before centrifuging at $10,000 \mathrm{rpm}$ for $7 \mathrm{~min}$ at $5{ }^{\circ} \mathrm{C}$. The supernatant was filtered through the Chromafil AO45/25 polyamide filter (Macherey-Nagel, Düren, Germany) into a vial. The analysis of phenolic compounds was carried out using the Surveyor system with a diode array detector (DAD) controlled by a Chromo-Quest 4.0 chromatography workstation software systems (Thermo Scientific, San Jose, CA). The column Gemini C18 (150 $\mathrm{x} 4.6 \mathrm{~mm}$; Phenomenex, Torrence, CA) with particle size of $3 \mu \mathrm{m}$ maintained at $25^{\circ} \mathrm{C}$ was used for the separation. The spectra of phenolic compounds were also recorded between 210 and $400 \mathrm{~nm}$ (Bakhshi and Arakawa, 2006). The phenolic compounds were identified by their retention times and the use of external standards. The elution solvents were $1 \%$ aqueous formic acid (A) and $100 \%$ acetonitrile (B) with the flow rate maintained at $1 \mathrm{ml} \mathrm{min}{ }^{-1}$ and injection amount was $20 \mu \mathrm{l}$.

The gradient method used was as described by Marks et al. (2007). All phenolic compounds presented in our results were identified by an HPLC- Finnegan MS detector and a LCQ Deca XP MAX (Thermo Finnegan, San Jose, CA) instrument with electrospray interface (ESI) operating in negative ion mode. The analyses were performed using full-scan, data dependent $\mathrm{MS}^{2}$ 
scanning from $\mathrm{m} / z 115$ to 2000 . Column and chromatographic conditions were identical to those used for the HPLC-DAD analyses. The concentrations of phenolic compounds were calculated with help of a corresponding external standard and were expressed in $\mathrm{mg} \mathrm{kg}^{-1}$ of FM. The total analysed phenolics were the sum of detected individual phenolics.

\subsection{STATISTICAL ANALYSIS}

Data were reported as the mean \pm standard error of five replicates. The results were compared by one-way analysis of variance (ANOVA) and the determined differences were tested by Tukey test at a significance level of 0.05 (using the SPSS 16 program). Principal component analysis (PCA), using STATGRAFICS Centurion XVI (Version 16.1.11) Programme has been used to discriminate between cultivars (traditional and commercial apple cultivars) and part of fruit (pulp and peel) in relation to phenol compounds as well organic acid and sugar profiles.

\section{RESULTS AND DISCUSSIONS}

The content of sugars and organic acids, which depend on the plant genotype (Begić-Akagić et al., 2006, Begić-Akagić et al., 2014), is also influenced by environmental factors and by horticultural practise undertaken in an orchard (Hudina and Štampar, 2006). The total sugar content of the cultivars 'Idared, 'Jonagold', 'Granny Smith' and 'Prijedorska Zelenika' ranged between 91.61 and $105.45 \mathrm{~g} \mathrm{~kg}^{-1}$ and there was influence of cultivar on the total sugar content. The highest content was achieved at cultivar 'Idared' (105.45 $\mathrm{g} \mathrm{kg}^{-1}$ ) which was lower than that reported by Hecke et al. (2006). It could be explained by different environmental factors as well as horticultural practise undertaken in an orchard. Fructose was the most abundant sugar of all quantified ones in apple fruit (Table 1) followed by sucrose and glucose.

All cultivars - whether local or commercial - contain more fructose and less glucose, a fact that is an advantage for diabetes patients, since it helps to keep the blood-sugar level constant. These results are in accordance with other investigations on apple cultivars reported in the literature (Veberič et al., 2003; Veberič et al., 2005; Hecke et al., 2006; Wang et al., 2010; BegićAkagić et al., 2014). We found significant differences in all analysed sugars (sucrose, glucose, fructose and sorbitol content) as well glucose/fructose ratio between analysed apple cultivars. Sorbitol accounted on average up to $0.0047 \mathrm{~g} \mathrm{~kg}^{-1} \mathrm{FM}$, the highest contents were achieved by commercial cultivars 'Granny Smith' and 'Prijedorska Zelenika' local ones. Content of sorbitol was lower in all analysed apple cultivars than those reported by Šturm and Štampar (1999), Wang et al. (2010) and Mikulič Petkovšek et al. (2009). Chan et al. (1972) suggested that higher relative sorbitol content of apple cultivars during late fruit growth is associated with water core development and therefore with lower quality of the fruits because of source limitations in environment. Fruits from 'Prijedorska Zelenika' local apple cultivar had the lowest content of sucrose and fructose and the highest glucose content and glucose/fructose ratio. On the other hand, commercial apple cultivar 'Granny Smith' had the lowest content of glucose, total sugar and glucose/fructose ratio. The highest fructose and total sugar content were observed in the fruits of 'Idared' apple cultivar.

The total organic acid content of all cultivars ranged between 5.70 ('Idared') and 15.05 ('Prijedorska Zelenika') $\mathrm{g} \mathrm{kg}^{-1} \mathrm{FM}$ (Table 2).

The level of total organic acid was higher in local apples than in commercial cultivars and there were statistically significant differences between them. Probably this is due to the fact that modern cultivars are selected for less acid taste. Although Fischer et al. (1995) reported that sweeter taste is more often inherited from the parents

Table 1: The content of individual sugars in different apple cultivars ( $\mathrm{g} \mathrm{kg}^{-1}$ fresh mass). Each mean is the average of 5 replicates

\begin{tabular}{|c|c|c|c|c|}
\hline \multirow[b]{2}{*}{ Individual sugars } & \multicolumn{4}{|l|}{ Cultivars } \\
\hline & 'Idared" & 'Jonagold' & 'Granny Smith' & 'Prijedorska Zelenika' \\
\hline Sucrose & $22.56 \pm 0.98^{\mathrm{a}}$ & $22.77 \pm 0.11^{\mathrm{a}}$ & $22.23 \pm 2.89^{\mathrm{ab}}$ & $18.11 \pm 1.14^{\mathrm{b}}$ \\
\hline Fructose & $62.87 \pm 1.96^{\mathrm{a}}$ & $59.38 \pm 2.49^{\mathrm{ab}}$ & $55.41 \pm 5.90^{\mathrm{bc}}$ & $53.38 \pm 2.49^{c}$ \\
\hline Glucose & $20.01 \pm 0.33^{\mathrm{ab}}$ & $18.64 \pm 0.73^{\mathrm{b}}$ & $13.96 \pm 0.61^{\mathrm{c}}$ & $20.54 \pm 0.86^{\mathrm{a}}$ \\
\hline Sorbitol & $0.0025 \pm 0.0004^{\mathrm{b}}$ & $0.0023 \pm 0.0004^{\mathrm{b}}$ & $0.0047 \pm 0.0001^{\mathrm{a}}$ & $0.003 \pm 0.0001^{\mathrm{b}}$ \\
\hline Total sugar & $105.45 \pm 2.42^{\mathrm{a}}$ & $100.80 \pm 3.34^{\mathrm{a}}$ & $91.61 \pm 2.93^{\mathrm{b}}$ & $91.74 \pm 3.97^{\mathrm{b}}$ \\
\hline Glucose/Fructose ratio & $0.32 \pm 0.005^{\mathrm{b}}$ & $0.31 \pm 0.001^{\mathrm{b}}$ & $0.25 \pm 0.01^{\mathrm{c}}$ & $0.39 \pm 0.03^{\mathrm{a}}$ \\
\hline
\end{tabular}

${ }^{*}$ Different letters in rows from a to $\mathrm{c}$ for each individual sugar indicate significantly different values among apple cultivars at $p<0.05$. 
Table 2: Content of individual organic acids in different apple cultivars ( $\mathrm{g} \mathrm{kg}^{-1}$ fresh mass). Each mean is the average of 5 replicates

\begin{tabular}{lllll}
\hline & \multicolumn{2}{l}{ Cultivars } & & \\
\cline { 2 - 5 } Individual organic acid & 'Idared” & 'Jonagold' & 'Granny Smith' & 'Prijedorska Zelenika' \\
\hline Malic acid & $4.76 \pm 0.38^{\mathrm{c}}$ & $9.38 \pm 0.38^{\mathrm{a}}$ & $6.03 \pm 0.54^{\mathrm{b}}$ & $8.92 \pm 0.13^{\mathrm{a}}$ \\
Citric acid & $0.74 \pm 0.10^{\mathrm{c}}$ & $0.92 \pm 0.18^{\mathrm{c}}$ & $1.75 \pm 0.16^{\mathrm{b}}$ & $5.64 \pm 0.89^{\mathrm{a}}$ \\
Shikimic acid & $0.19 \pm 0.04^{\mathrm{c}}$ & $0.19 \pm 0.02^{\mathrm{c}}$ & $0.25 \pm 0.06^{\mathrm{b}}$ & $0.45 \pm 0.11^{\mathrm{a}}$ \\
Fumaric acid & $0.005 \pm 0.001^{\mathrm{c}}$ & $0.007 \pm 0.001^{\mathrm{bc}}$ & $0.013 \pm 0.001^{\mathrm{b}}$ & $0.030 \pm 0.005^{\mathrm{a}}$ \\
Total acids & $5.70 \pm 0.39^{\mathrm{d}}$ & $10.51 \pm 0.43^{\mathrm{b}}$ & $8.05 \pm 0.52^{\mathrm{c}}$ & $15.05 \pm 1.69^{\mathrm{a}}$ \\
Sugar/acid ratio & $18.56 \pm 1.07^{\mathrm{a}}$ & $9.60 \pm 0.61^{\mathrm{c}}$ & $11.40 \pm 0.38^{\mathrm{b}}$ & $6.10 \pm 0.27^{\mathrm{d}}$ \\
\hline
\end{tabular}

* Different letters in rows from a to $\mathrm{d}$ for each organic acid indicate significantly different values among apple cultivars at $p<0.05$.

than acid taste. Our results are in agreement with Hecke et al. (2006) which reported values of total acid between 6.26 and $17.85 \mathrm{~g} \mathrm{~kg}^{-1}$ FM. Malic acid is the main single component of the total acids of the cultivars and ranged from 4.76 ('Idared') to $9.38 \mathrm{~g} \mathrm{~kg}^{-1}$ ('Jonagold'). Very low content of citric acid were found (0.74-1.75 $\mathrm{g} \mathrm{kg}^{-1} \mathrm{FM}$ ) in commercial cultivars while local cultivar 'Prijedorska Zelenika' showed up to 7 times more citric acid than the other analysed cultivars. Our results are in agreement with those reported by Carbonaro et al. (2002), who found an increase in the content of citric acid in organically grown peaches compared to conventionally grown. Shikimic acid content were highest in 'Prijedorska Zelenika' (local) while commercial cultivars contained in the range between $0.19-0.25 \mathrm{~g} \mathrm{~kg}^{-1} \mathrm{FM}$, and there were significant differences in shikimic acid between commercial apple cultivars and local ones. Hecke et al. (2006) reported similar data for apple cultivars with shikimic acid content between $0.002 \mathrm{~g} \mathrm{~kg}^{-1} \mathrm{FM}$ and $0.057 \mathrm{~g} \mathrm{~kg}^{-1}$ FM. Fumaric acid was presented in lower quantities compared to other analysed acids. The highest content was achieved by local grown cultivar 'Prijedorska Zelenika' and the lowest content by commercial cultivar 'Idared' (0.005 $\left.\mathrm{g} \mathrm{kg}^{-1} \mathrm{FM}\right)$ and there were significant differences between cultivars. Shui and Leong (2002) noticed that the low content of fumaric acid in apple juice indicates its authenticity and good quality. Same authors reported that fumaric acid content $10 \mathrm{mg} \mathrm{l}^{-1}$ in apple juice drink could be due to the addition of synthetic malic acid as well microbial spoilage due to the presence of Rhizopus stolonifer Vuillemin in juice drink. The sugar/acid ratio is responsible for the taste and flavour of apples (Mikulič Petkovšek et al., 2007; Wu et al., 2007). Apple cultivars with sugar/acid rations lower than 20 are sharp and appropriate processing and cider production, while cultivars with sugar/acid rations higher than this value are sweet, and good for direct consumption (Lee et al., 2003). As it can be seen from Table 2, all analyzed cultivars had sugar/acid rations lower than 20 , being classified as sour- sweet or sour cultivars. Vieira et al. (2009), Paganini et al. (2004) and Nogueira et al. (2006) found for apples of different cultivars grown in Brazil rations of 31.5-66.80.

The occurrence and distribution of the main polyphenol groups differed between peel and flesh as reported previous by Khanizadeh et al. (2008) and Giomaro et al. (2014). Ten phenolic compounds belong to three major phenolic groups and were identified in apples peel (Table 3).

They are flavonols (quercetin 3-O-xyloside, quercetin 3-O-arabinoside, quercetin 3-O-rhamnoside, quercetin 3-O-rutinoside, quercetin 3-O-galactoside and quercetin 3-O-glucoside), flavan-3-ols (catechin and epicatechin) and hydroxycinnamic acids (chlorogenic acid and caffeic acid). Major phenols in apple peel were flavonols (60.18 \%) and flavan-3-ols (24.30\%), followed by phenolic acids (15.51\%), which is similar with earlier reported results (Sun et al., 2002; Wolfe and Liu, 2003; Thielen et al., 2005; Kschonsek et al., 2018). It could be because fruits from analyzed apple cultivars were picked from the outer layer of the trees and according to Awad et al. (2001) total flavonoid content is much lower due to lower light level if apples were used from the inner layer of the tree. Wolfe et al. (2003) reported that apple peel has unique flavonoids, such as quercetin glycoside, not found in the flesh part of an apple and has three to six fold more flavonoids than apple pulp. Significant differences in all individual phenol compounds were observed among analysed apple cultivars. Quercetin 3-O-arabinoside was the main compound of all apple cultivars among the phenols determined, followed by quercetin 3-O-galactoside, 3-O-glucoside, 3-O-rutinoside, 3-O-rhamnoside, 3-Oxyloside in case of commercial apple cultivars with interchanging of galactoside and glucoside depending of the apple cultivars. The concentration of the quercetin derivates of traditional apple cultivar followed the order: arabinoside $>$ rutinoside $>$ rhamnoside $>$ galactoside $>$ glucoside $>$ xyloside. Quercetin 3-O-arabinoside was in the range $115.36-351.77 \mathrm{mg} \mathrm{kg}^{-1} \mathrm{FM}$. The values 
Table 3: Content of phenolic compounds in the apple peel ( $\mathrm{mg} \mathrm{kg}^{-1}$ fresh mass) in different apple cultivars. Each mean is the average of 5 replicates.

\begin{tabular}{lllll}
\hline & \multicolumn{3}{l}{ Cultivars } & \\
\cline { 2 - 4 } Individual phenolic compounds & 'Idared & 'Jonagold' & 'Granny Smith' & 'Prijedorska Zelenika' \\
\hline Catehin & $289.37 \pm 17.88^{\mathrm{a}}$ & $51.67 \pm 2.94^{\mathrm{c}}$ & $32.02 \pm 2.76^{\mathrm{c}}$ & $211.35 \pm 8.32^{\mathrm{b}}$ \\
Chlorogenic acid & $133.82 \pm 16.07^{\mathrm{b}}$ & $105.75 \pm 7.60^{\mathrm{b}}$ & $23.95 \pm 1.76^{\mathrm{c}}$ & $255.60 \pm 13.59^{\mathrm{a}}$ \\
Caffeic acid & $22.04 \pm 1.98^{\mathrm{b}}$ & $25.20 \pm 1.84^{\mathrm{b}}$ & $14.75 \pm 0.61^{\mathrm{c}}$ & $40.25 \pm 4.51^{\mathrm{a}}$ \\
Epicatechin & $81.24 \pm 4.84^{\mathrm{b}}$ & $79.95 \pm 9.23^{\mathrm{b}}$ & $53.21 \pm 2.35^{\mathrm{c}}$ & $180.98 \pm 7.66^{\mathrm{a}}$ \\
Q- xyloside & $12.98 \pm 2.49^{\mathrm{b}}$ & $20.39 \pm 2.20^{\mathrm{a}}$ & $4.01 \pm 0.56^{\mathrm{c}}$ & $8.40 \pm 0.25^{\mathrm{c}}$ \\
Q-arabinoside & $341.85 \pm 23.55^{\mathrm{a}}$ & $351.77 \pm 16.87^{\mathrm{a}}$ & $115.36 \pm 6.93^{\mathrm{b}}$ & $126.07 \pm 7.39^{\mathrm{b}}$ \\
Q-rhamnoside & $31.48 \pm 3.05^{\mathrm{b}}$ & $27.44 \pm 2.99^{\mathrm{b}}$ & $14.25 \pm 1.14^{\mathrm{c}}$ & $54.69 \pm 2.18^{\mathrm{a}}$ \\
Q-rutinoside & $132.57 \pm 15.21^{\mathrm{a}}$ & $100.20 \pm 5.11^{\mathrm{ab}}$ & $49.93 \pm 2.76^{\mathrm{ab}}$ & $64.49 \pm 1.61^{\mathrm{b}}$ \\
Q-galactoside & $284.34 \pm 59.17^{\mathrm{a}}$ & $103.83 \pm 25.63^{\mathrm{b}}$ & $63.42 \pm 7.54^{\mathrm{b}}$ & $41.32 \pm 15.64^{\mathrm{b}}$ \\
Q-glucoside & $128.25 \pm 23.89^{\mathrm{a}}$ & $126.79 \pm 25.20^{\mathrm{a}}$ & $57.02 \pm 5.45^{\mathrm{b}}$ & $32.64 \pm 6.80^{\mathrm{b}}$ \\
\hline
\end{tabular}

${ }^{*}$ Different letters in rows from a to $\mathrm{c}$ for each phenolic compounds indicate significantly different values among apple cultivars at $\mathrm{p}<0.05$.

${ }^{*}$ Q-xyloside: quercetin 3-O-xyloside, Q-arabinoside: quercetin 3-O-arabinoside, Q-rhamnoside: quercetin 3-O-rhamnoside, Q-rutinoside:quercetin 3-O-rutinoside, Q-galactoside: quercetin 3-O-galactoside, Q-glucoside: quercetin 3-O-glucoside

of quercetin 3-O-galactoside of apple cultivars ranging from 41.32 to $284.34 \mathrm{mg} \mathrm{kg}{ }^{-1} \mathrm{FM}$ and $32.64-128.25$ for quercetin 3-O-glucoside. The obtained results are consistent with those values reported by Khanizadeh et al. (2008) $\left(86.4-310.2 \mu \mathrm{g} \mathrm{g}^{-1} \mathrm{FM}\right.$ and $24.1-161.9 \mu \mathrm{g} \mathrm{g}^{-1}$ FM respectively). Researchers Tsao et al. (2003) and Kschonsek et al. (2018) identified quercetin 3-O-galactoside and quercetin 3-O-arabinoside as more important quercetin in analysed apple cultivars while Mehrabani et al. (2012) found quercetin 3-O-galactoside as the predominant phenolic compounds in 'Gala' apple peel of total identified compounds. Veberič et al. (2005) reported quercetin 3-O-rutinoside and quercetin 3-O-rhamnoside as the most important in apple peel. Quercetin is an important phenol with antioxidative properties; however, it is much more easily taken up in the human body in the form of glycosides, which are afterwards transformed into quercetin. Therefore, the amount of quercetin 3-Oglycosides could be important for nutritional value of apples (Lee et al., 2003). Chlorogenic acid, epicatechin and caffeic acid were the most abundant compounds only in local cultivar 'Prijedorska Zelenika' $(255.60 \mathrm{mg}$ $\mathrm{kg}^{-1}, 180.98$ and $40.25 \mathrm{mg} \mathrm{kg}^{-1} \mathrm{FM}$ respectively) and these showed significant higher amount of chlorogenic acid, epicatechin and caffeic acid than others commercial apple cultivars. The average chlorogenic acid content in analysed apple peel cultivars was $129.78 \mathrm{mg} \mathrm{kg}^{-1}$ that was consisted with results obtained by Tsao et al. (2003) who found the amount of chlorogenic acid in the peel in eight apple cultivars was $136 \mathrm{mg} \mathrm{kg}^{-1}$. Catechin content was significantly the highest in 'Idared' $\left(289.37 \mathrm{mg} \mathrm{kg}^{-1}\right.$ ) commercial apple cultivars than other analyzed cultivars
(211.35, 51.67 and $32.02 \mathrm{mg} \mathrm{kg}^{-1} \mathrm{FM}$ respectively). The results for the phenol compounds of analysed apple cultivars in this research demonstrated that the four apple cultivars are different in terms of their content of individual phenolics in the apple peel as well apple pulp. In addition, these compounds vary greatly among the studies cited and among the regions considered by the researchers. This may be due to the specific geographical nature of the different areas and different agronomical practices. It is also well known that the plant genotype strongly affects the chemical composition of apples (Vieira et al., 2009; Valavanidis et al., 2009; Vieira et al., 2011; Vranac et al., 2014). Thus, the differences in the apple cultivars in term of phenolic compounds are attributed to the origin of the plant material since all cultivars were grown under the same geographical conditions and with the same applied agronomic practice.

Generally, there was a lower content of individual phenolics in the fruit pulp, compared with the phenolics in the apple peel. The relationship between the content of individual phenolics in the apple peel and apple pulp is presented in Table 5. Chlorogenic acid, caffeic acid and epicatechin were the only phenolic compounds found in apple pulp (Table 4).

Traditional cultivar ('Prijedorska Zelenika') showed significantly higher contents of individual and total phenolic compounds analysed in the apple pulp compared with the commercial apple cultivars. Higher level of phenolic compounds in traditional cultivar could be a mechanism of plant response to biotic and abiotic stressors (diseases, pests, lack of mineral nutrients, ...). A great variation in terms of chlorogenic acid content 
Table 4: Content of phenolic compounds in the apple pulp ( $\mathrm{mg} \mathrm{kg}^{-1}$ fresh mass) in different apple cultivars. Each mean is the average of 5 replicates

\begin{tabular}{lllll}
\hline & Cultivars & & & \\
\cline { 2 - 5 } Individual phenolic compounds & 'Idared” & 'Jonagold' & 'Granny Smith' & 'Prijedorska Zelenika' \\
\hline Chlorogenic acid & $152.14 \pm 9.91^{\mathrm{b}}$ & $112.14 \pm 5.6^{\mathrm{c}}$ & $63.48 \pm 4.96^{\mathrm{d}}$ & $365.62 \pm 8.77^{\mathrm{a}}$ \\
Caffeic acid & $5.50 \pm 0.47^{\mathrm{c}}$ & $6.00 \pm 0.70^{\mathrm{c}}$ & $14.45 \pm 0.57^{\mathrm{b}}$ & $18.88 \pm 1.09^{\mathrm{a}}$ \\
Epicatechin & $14.28 \pm 0.66^{\mathrm{c}}$ & $14.05 \pm 0.75^{\mathrm{c}}$ & $35.66 \pm 1.05^{\mathrm{b}}$ & $55.33 \pm 2.56^{\mathrm{a}}$ \\
\hline
\end{tabular}

* Different letters in rows from a to $\mathrm{d}$ for each phenolic compounds indicate significantly different values among apple cultivars at $p<0.05$.

was observed among the apple cultivars ranging from $63.48 \mathrm{mg} \mathrm{kg}^{-1} \mathrm{FM}$ ('Granny Smith') to $365.62 \mathrm{mg} \mathrm{kg}^{-1} \mathrm{FM}$ ('Prijedorska Zelenika') and the differences were statistically significant $(p<0.05)$. The results confirmed earlier reports that chlorogenic acid was the most abundant phenolic compound in apple pulp (Wu et al., 2007; Khanizadeh et al., 2007; Mehrabani et al., 2011; Vranac et al., 2014). Ding et al (2001) and Tokuşoğlu (2011) reported that chlorogenic acid is a high-valued phenolic constituent because of its great role in enzymatic browning of processed fruits. The content of chlorogenic acid in the apple pulp of analysed cultivars was higher than in the peel. In apple cultivar ('Jonagold'), the ratio between pulp and peel in concentration of chlorogenic acid was 0.95 . Similar pattern was observed in cultivars 'Idared' (0.89) and 'Prijedorska Zelenika' (0.70) with exception for 'Granny Smith' (0.38) (Table 5).

The second highest amount of determined individual phenolic compounds in the pulp was epicatechin, which was ranging from $14.05 \mathrm{mg} \mathrm{kg}^{-1} \mathrm{FM}$ ('Jonagold') to $55.33 \mathrm{mg} \mathrm{kg}^{-1} \mathrm{FM}$ ('Prijedorska Zelenika') and was higher than the amount reported by Veberič et al. (2005), who noted values of epicatechin ranging from $0.17 \mathrm{mg} \mathrm{kg}^{-1} \mathrm{FM}$ to $1.24 \mathrm{mg} \mathrm{kg}^{-1} \mathrm{FM}$ in the pulp of 'Bohnapfel' apples but similar with those reported by Khanizadeh et al., (2008) (36.9 - $109.0 \mu \mathrm{g} \mathrm{g}^{-1} \mathrm{FM}$ ). The content of epicatechin in the peel was from 1.49 to 5.69 times higher than in the pulp (Table 5). The flavanols, especially the procyanidins in previous studies, were the major group of apple polyphenols in both peel and pulp, representing more than $80 \%$ of the total polyphenol content (Tsao et al., 2003;
Wojdilo et al., 2008; Khanizadeh et al., 2008). In this study, the content and percentage of flavanols were lower than the quantities reported by other researchers. One possible reason for this may be the desintegration of the apples without adding an antioxidant as ascorbic acid. As described by Guyot et al. (1998) flavanol monomers and procyanidins are good substrates for polyphenol oxidase and are directly involved in enzymatic oxidation, occurring when apples are crushed. The content of caffeic acid was the lowest among analyzed individual phenolic compounds in the apple pulp ranging from $5.50 \mathrm{mg} \mathrm{kg}^{-1} \mathrm{FM}$ to $18.88 \mathrm{mg} \mathrm{kg}^{-1} \mathrm{FW}$ ('Prijedorska Zelenika'). Our results are in well conformity with the finding of Mehrabani et al. (2011) in apple. Reinders et al. (2001) indicated that caffeic acid, one of the dominant apple phenolic acids, might have an impact or inhibitory effect on Escherichia coli $\mathrm{O} 157: \mathrm{H7}$ in an apple juice model medium.

Comparing the data of total phenolics in the peel and pulp, apple peel contain from 2.31 ('Prijedorska Zelenika') to 8.52 ('Idared') times greater total phenolic content than apple pulp (Table 6).

However, in the case of cloudy apple juice processing traditional cultivar 'Prijedorska Zelenika' is better row material for processing than commercial cultivars because during apple processing into cloudy juice the apple skin was removed. Therefore, the phenols in the pulp are of the greater importance to consumer than the ones in the peel. On the other hand, the peel comprises only small percentage of the entire fruit weight, its significance as a donor of phenols is disputable. Lata et al. (2009) reported on average $8,24,32,50$ and $66 \%$ of chlorogenic

Table 5: Relationship between the content of phenolic compounds in the apple peel and apple pulp (content in apple peel/content apple pulp) in different apple cultivars

\begin{tabular}{|c|c|c|c|c|}
\hline \multirow[b]{2}{*}{ Individual phenolic compounds } & \multicolumn{4}{|l|}{ Cultivars } \\
\hline & 'Idared' & 'Jonagold' & 'Granny Smith' & 'Prijedorska Zelenika' \\
\hline Chlorogenic acid & $0.89 \pm 0.15^{\mathrm{b}}$ & $0.95 \pm 0.11^{\mathrm{b}}$ & $0.38 \pm 0.031^{\mathrm{b}}$ & $0.70 \pm 0.02^{\mathrm{a}}$ \\
\hline Caffeic acid & $4.04 \pm 0.59^{\mathrm{a}}$ & $4.24 \pm 0.49^{\mathrm{a}}$ & $1.02 \pm 0.08^{\mathrm{c}}$ & $2.13 \pm 0.14^{\mathrm{b}}$ \\
\hline Epicatechin & $5.69 \pm 0.19^{\mathrm{a}}$ & $5.68 \pm 0.36^{\mathrm{a}}$ & $1.49 \pm 0.11^{\mathrm{c}}$ & $3.28 \pm 0.29^{b}$ \\
\hline
\end{tabular}

* Different letters in rows from a to $c$ for each phenolic compounds indicate significantly different values among apple cultivars at $p<0.05$. 
Table 6: Total phenolic compounds analysed in the peel and pulp of different cultivars ( $\mathrm{mg} \mathrm{kg}^{-1} \mathrm{fresh}$ mass) and relationship between the total phenolics in the apple peel and pulp

\begin{tabular}{llll}
\hline Cultivar & Peel $^{*}$ & Pulp & Ratio peel/pulp \\
\hline 'Idared' & $1457.95 \pm 150.61^{\mathrm{a}}$ & $171.92 \pm 9.06^{\mathrm{b}}$ & $8.52 \pm 1.25^{\mathrm{a}}$ \\
'Jonagold' & $992.98 \pm 44.74^{\mathrm{b}}$ & $132.18 \pm 6.80^{\mathrm{c}}$ & $7.51 \pm 0.05^{\mathrm{a}}$ \\
'Granny Smith' & $427.92 \pm 9.59^{\mathrm{c}}$ & $113.58 \pm 5.59^{\mathrm{c}}$ & $3.77 \pm 0.21^{\mathrm{b}}$ \\
'Prijedorska Zelenika' & $1015.79 \pm 40.57^{\mathrm{b}}$ & $439.83 \pm 12.28^{\mathrm{a}}$ & $2.31 \pm 0.04^{\mathrm{b}}$ \\
\hline
\end{tabular}

* Different letters in columns from a to $\mathrm{c}$ for phenol compounds both in apple pulp and peel indicate significantly different values among apple cultivars at $p<0.05$.

acid, catechin, epicatechin, phloridzin and rutin, respectively, were present in the peel, which constitutes about 6-8 \% of the whole apple weight. Statistically significant the highest content of total phenolic compounds in apple peel was in the cultivar 'Idared' ( $1457.95 \mathrm{mg} \mathrm{kg}^{-1} \mathrm{FM}$ ) and the lowest content was in the cultivar 'Granny Smith' (427.92 $\mathrm{mg} \mathrm{kg}^{-1} \mathrm{FM}$ ). Cultivar with significantly the highest content of phenolics in the pulp was traditional fruit 'Prijedorska Zelenika' (439.83 $\mathrm{mg} \mathrm{kg}^{-1} \mathrm{FM}$ ) compared to the commercial cultivars. Our results are consistent with those reported by Kschonsek et al. (2018) who noticed significantly higher content of total phenolic compounds in pulp between old and new apple cultivars. Above reported results are confirmed by principal component analysis (Figure 1).

A three factor component analysis was applied and two factor showing an eigenvalue greater than 1 , explaining $90.64 \%$ variability. Figure 1 shows the score plot of PCA on the sugar, acid and phenol profile of apples, where separation between cultivars (traditional and commercial ones) and part of fruit can be seen. It is obvious that traditional cultivar 'Prijedorska Zelenika' was determinate with fumaric acid, shikimic, citric, total acid, glucose/fructose ratio, glucose, total sugar, chlorogenic acid, caffeic acid and epicatechin, total phenol both in the pulp and in the apple skin as well chlorogenic acid skin/pulp ratio, epicatechin skin/pulp ratio, caffeic acid skin/pulp ratio and with quercetin derivates in the peel.

The most dominant apple cultivars ('Idared' and 'Jonagold') in Bosnia and Herzegovina are located in negative part of PC1 component and were determined with sugar/acid ratio, total sugar, sucrose, fructose, chlorogenic acid skin/pulp ratio, epi catechinskin/pulp ratio, caffeic acid skin/pulp ratio, total phenol skin/pulp ratio

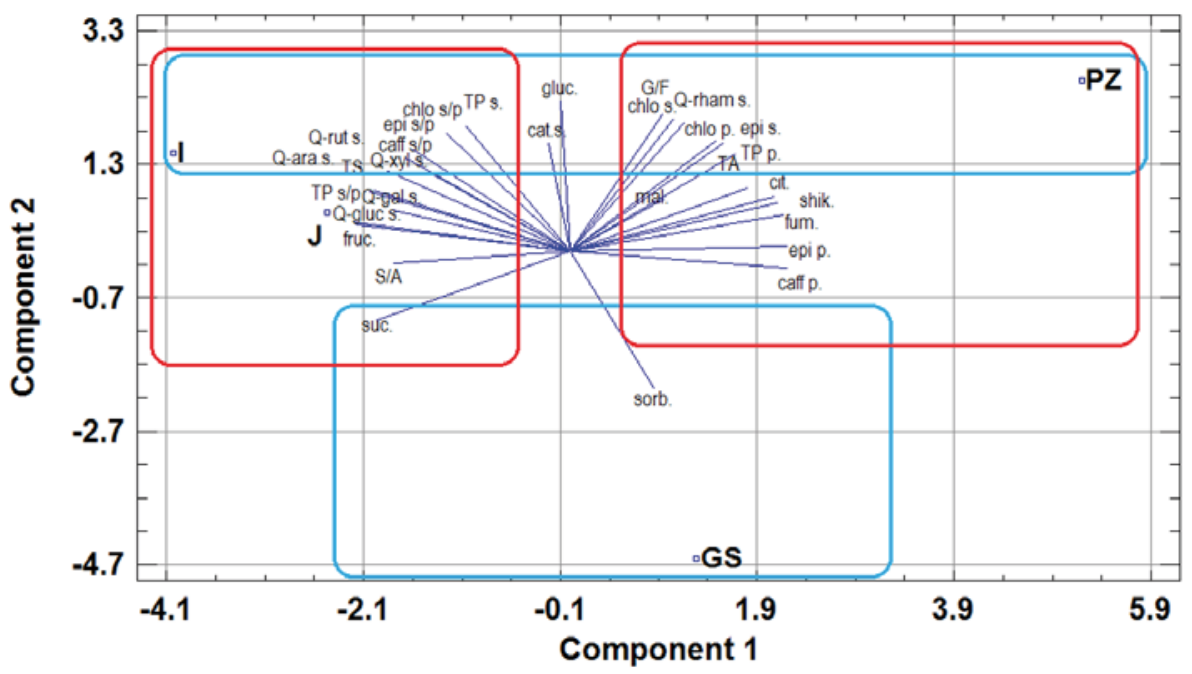

Figure 1: PCA biplot of the individual sugar, acid and the phenol compounds in different apple cultivars (gluc - glucose, fruc - fructose, suc - sucrose, sorb - sorbitol, TS - total sugars, G/F - glucose/fructose ratio, mal - malic acid, cit - citric acid, fum - fumaric acid, Shik - shikimic acid, TA - total acids, S/A - total sugar/acid ratio, chlo - chlorogenic acid, caff -caffeic acid, cat - catehin, epi - epicatehin, Q-rham - quercetin 3-O-rhamnoside; Q-glu-quercetin 3-O-glucoside; Q-rut - quercetin 3-O-rutinoside; Q-ara - quercetin 3-O-arabinoside; Q-gal - quercetin 3-O-galactoside; Q-xyl - quercetin 3-O-xyloside; s - skin; p - pulp, s/p - skin/pulp ratio, PZ - 'Prijedorska Zelenika' GS - 'Granny Smith', J - 'Jonagold', I - 'Idared'). 
as well quercetin derivates except quercetin 3-O-rhamnoside in the skin.

On the other hand, cultivar 'Idared' is also located in positive part of PC2 component and with upon mentioned components was determine with glucose, glucose/ fructose ratio, total sugar, total acid, malic acid, chlorogenic acid both in skin and pulp, chlorogenic acid skin/ pulp ratio, epi catechinskin/pulp ratio, caffeic acid skin/ pulp ratio and caffeic acid, total phenol and quercetin derivates (except quercetin 3-O-glucoside) only in the peel, what is the main difference in relation to 'Jonagold' cultivar.

Commercial cultivar 'Granny Smith' is located in negative part of PC2 component and was determined with sucrose and sorbitol content.

General it can be concluded that traditional apple cultivar 'Prijedorska Zelenika' was separated between analysed cultivars with acid content as well valuable polyphenol components. According to those traditional apple cultivar 'Prijedorska Zelenika' may be used for polyphenol enriching of different fruit products special juices made from commercial apple cultivars as well harmonise taste of them with acids.

\section{CONCLUSIONS}

There is a growing demand for processed and semiprocessed apple fruits, and for products adapted to specific climate such as cloudy apple juice and cider, which can help to improve the fruit industry and make it more competitive. The development of new apple cultivars for processing is a long-term and expensive project, and using the traditional (autochthonous) apple cultivars, which are more tolerant to diseases as well rich in nutritive (sugar and organic acid) and non-nutritive compounds such as polyphenolics, can help to improve offer of apple processed products at the market. This investigation demonstrated the sugar, organic acid and phenolic composition of traditional and commercial apple cultivars. We can conclude that the type of cultivar (traditional and commercial) affected the sugar and organic acid contents in the fruits. All analysed cultivars had sugar/ acid rations lower than 20, being classified as sour-sweet or sour cultivars. Quantitative analysis of different apple cultivars, traditional and commercial, showed significant differences in total phenolics in the both apple pulp and skin. As expected, skins for all cultivars of apples showed around a 2.31- to 8.52-fold higher total phenolic compound than the apple pulp. 'Prijedorska Zelenika' fruits showed the highest total phenolic into the pulp among the four cultivars. Ten phenolic compounds in apple peel of different apple cultivars were identified while only three of them were found in the apple pulp. Variation in phenolic compounds content of apple fruits depends mainly upon cultivar and part of apple fruit (skin and pulp). As a result of the importance of phenolic compounds for human health and sensory attributes for apple products, we recommend the processing into cloudy juice of traditional cultivar 'Prijedorska Zelenika' or blending it with commercial ones.

\section{ACKNOWLEDGEMENTS}

This study was part of the Horticulture No. P4-00130481 Programme as well as the Programme in Higher Education, Research and Development in the Western Balkans (HERD/Agriculture) "Evaluation of fruit genetic resources in Bosnia-Herzegovina with the aim of sustainable, commercial utilization". The authors thank the Slovenian Research Agency and the Ministry of Education and Science of the Federation of Bosnia and Herzegovina for financial support.

\section{REFERENCES}

Alberto, M.R., Canavosio, M.A.R., Nadra, M.C.M. (2006). Antimicrobial effect of polyphenols from apple skins on human bacterial pathogens. Electronic Journal of Biotechnology, 9(3), 205-209. https://doi.org/10.2225/vol9-issue3fulltext-1

Alonso-Salces, R.M., Barranco, A., Abad, B., Berruetta, L.A., Gallo, B., Vicente, F. (2004). Polifenolic profiles of Basque Cider Apple Cultivars and Their Technological Properties. Journal of Agricultural and Food Chemistry, 52(10), 293852. https://doi.org/10.1021/jf0354161

Amiot, M.J., Tacchini, M., Aubert, S., Nicolas, J. (1992). Phenolic composition and browning susceptibility of Various Apple Cultivars at Maturity. Journal of Food Science, 57(4), 958-962. https://doi.org/10.1111/j.1365-2621.1992. tb14333.x

Awad, M.A., Wagenmakers, P.S., Jager, A. (2001). Effect of light environment on flavonoid and chlorogenic acid levels in the skin of 'Jonagold' apples. Scientia Horticulturae, 88, 289-298. https://doi.org/10.1016/S0304-4238(00)00215-6

Bakhshi, D., Arakawa, O. (2006). Induction of phenolic compounds biosynthesis with light irradiation in the flesh of red and yellow apples. Journal of Applied Horticulturae, 8, 101-104.

Begić-Akagić, A., Hadžić, S., Gaši, F., Kurtović, M. (2006). Evaluation of technological characteristics of the autochthonous apple genotypes in Bosnia and Herzegovina. Work of the Faculty of Agriculture, University of Sarajevo, 57(3), 117-125.

Begić-Akagić, A., Spaho, N., Gaši, F., Drkenda, P., Vranac, A., Meland, M., Salkić, B. (2014). Sugar and organic acid profiles of the traditional and international apple cultivars for 
processing. Journal of Hygienic Engineering and Design, 190-196.

Begić-Akagić, A., Spaho, N., Oručević, S., Drkenda, P., Kurtović, M., Gaši, F., Kopjar, M., Piližota, V. (2011). Influence of cultivar, storage time, and processing on the phenol content of cloudy apple juice. Croatian Journal of Food Science and Technology, 3, 1-8.

Bhuyan, D.J., Basu, A. (2017). Phenolic compounds: Potential Health Benefits and Toxicity. In: Utilisation of Bioactive Compounds from Agricultural and Food Production Waste. CRC Press, Taylor \& Francis Group, 27-59. https://doi. org/10.1201/9781315151540-3

Boudabous, M., Marzouk, I.B., Lechiheb, B., Yahia, I.B., Ferchichi, A. (2015). Journal of New Sciences, 24(2), 1091-97.

Boyer, J., Liu, R.H. (2004). Apple phytochemicals and their health benefits. Nutrition Journal, 3(5), 1-15. https://doi. org/10.1186/1475-2891-3-5

Carbone, K., Giannini, B., Picchi, V., Scalzo, R.L., Cecchini, F. (2011). Phenolic composition and free radical scavenging activity of different apple varieties in relation to the cultivar, tissue type and storage. Food Chemistry, 127, 493-500. https://doi.org/10.1016/j.foodchem.2011.01.030

Chan, W.W., Chong, C., Taper, C.D. (1972). Sorbitol and other carbohydrate variation during growth and cold storage of McIntosh apple fruits. Canadian Journal of Plant Science, 52, 743-750. https://doi.org/10.4141/cjps72-121

Corbonaro, M., Mattera, M., Nicoli, S., Bergamo, P., Cappelloni, M. (2002). Modulation of antioxidant compounds in organic vs conventional fruit (peach, Prunus persica L., and pear, Pyrus communis L.). Journal of Agriculure and Food Chemistry, 50, 5458-5462. https://doi.org/10.1021/ jf0202584

Ding, C.K., Chachin, K., Ueda, Y., Imahori, Y., Wang, C.Y. (2001). Metabolism of phenolic compounds during loquat fruit development. Journal of Agriculure and Food Chemistry, 49, 2883-2888. https://doi.org/10.1021/jf0101253

Drogoudi, P.D., Michailidis, Z., Pantelidis, G. (2008). Peel and flesh antioxidant content and harvest quality characteristics of seven apple cultivars. Scientia Horticulturae, 115, 149153. https://doi.org/10.1016/j.scienta.2007.08.010

Eberhardt, M.V., Lee, C.Y., Liu, R.H. (2000). Antioxidant activity of fresh apples. Nature, 405, 903-904. https://doi. org/10.1038/35016151

Fischer, M., Albrecht, H.J., Büttner, R., Fischer, C., Günter, M., Hartmman, W., Müller, E., Schuricht, W., Spellerberg, B., Störtzer, M., Wolfram, B. (1995). Farbatlas Obstsorten. Eugen Ulmer GmbH and Co., Stuttgart.

Giomaro, G., Karioti, A., Bilia, A.R., Bucchini, A., Giamperi, L., Ricci, D., Fraternale, D. (2014). Polyphenols profile and antioxidant activity of skin and pulp of a rare apple from Marche region (Italy). Chemistry Central Journal, 8, 45. https://doi.org/10.1186/1752-153X-8-45

Gutiérrez-Grijalva, E.P., Ambriz-Pére, D.L., Leyva-López, N., Castillo-López, R.I., Heredia, J.B. (2016). Review: dietary phenolic compounds, health benefits and bioaccessibility. Archivos Latinoamericanos de Nutricion, 66(2). http://www. alanrevista.org/ediciones/2016/2/art-1/.

Guyot, S., Marnet, N., Djamel, L., Sanoner, P., Drilleau, J.F. (1998). Reversed-phase HPLC following thiolysis for quan- titative estimation and characterization of the four main classes of phenolic compounds in different tissue zones of a French cider apple variety (Malus domestica Var. Kermerrien). Journal of Agriculure and Food Chemistry, 46, 1698-1705. https://doi.org/10.1021/jf970832p

Hecke, K., Herbinger, K., Veberič, R., Trobec M., Toplak, H., Štampar, F., Keppel, H., Grill, D. (2006). Sugar-, acid-, and phenol contents in apple cultivars from organic and integrated fruit cultivation. European Journal of Clinical Nutrition, 60, 1136-1140. https://doi.org/10.1038/sj.ejcn.1602430

Hertog, M.G.L., Hollman, P.C.H., Katan, M.B., Kromhout, D. (1993). Intake of potentially anticarcinogenic flavonoids and their determinants in adults in The Netherlands. Nutrition and Cancer, 20, 21-29. https://doi. org/10.1080/01635589309514267

Hudina, M., Štampar, F. (2006). Influence of frost damage on the sugars and organic acids contents in apple and pear flowers. European Journal of Horticultural Science, 71, 161-164.

Hyson, D.A. (2011). A comprehensive review of apples and apple components and their relationship to human health. Advances in Nutrition, 2, 408-420. https://doi. org/10.3945/an.111.000513

Jelodarian, S., Ebrahimabadi, A.H., Kashi, F.J. (2013). Evaluation of antimicrobial activity of Malus domestica fruit extract from Kashan area. Avicenna Journal of Phytomedicine, 3(1), 1-6.

Khanizadeh, S., Ding, L., Rekika, D., Yang, R., Charles, M.T., Vigneault, C., Rupasinghe, H.P.V. (2007). Phytochemical distribution among selected advanced apple genotypes developed for fresh market and processing. Journal of Agriculture and Environmental Sciences, 1(2), 13 p.

Khanizadeh, S., Tsao, R., Rekika, D., Yang, R., Charles, M.T., Rupasinghe, H.P.V. (2008). Polyphenol composition and total antioxidant capacity of selected apple genotypes for processing. Journal of Food Compositon and Analysis, 21, 396-401. https://doi.org/10.1016/j.jfca.2008.03.004

Kschonsek, J., Wolfram, T.,_Stöckl, A., Böhm, V. (2018). Polyphenolic Compounds Analysis of Old and New Apple Cultivars and Contribution of Polyphenolic Profile to the In Vitro Antioxidant Capacity. Antioxidants, 7(20), 14 p. https://doi.org/10.3390/antiox7010020

Lata, B., Trampczynska, A., Paczesna, J. (2009). Cultivar variation in apple peel and whole fruit phenolic composition. Scientia Horticulturae, 121, 176-181. https://doi. org/10.1016/j.scienta.2009.01.038

Lee, K.W., Kim, Y.J., Kim, D., Lee, H.J., Lee, C.Y. (2003). Major phenolics in apple and their contribution to the total antioxidant capacity. Journal of Agriculure and Food Chemistry, 51, 6516-6520. https://doi.org/10.1021/jf034475w

Lin, D., Xiao, M., Zhao, J., Li Z., Xing, B., Li, X., Kong, M., Li, L., Zhang, Q., Liu, Y., Chen, H., Qin, W., Wu, H., Chen, S. (2016). An Overview of Plant Phenolic Compounds and Their Importance in Human Nutrition and Management of Type 2 Diabetes. Molecules, 21(10), 19 p. https://doi. org/10.3390/molecules21101374

Marks, S.C., Mullen, W., Crozier, A. (2007). Flavonoid and chlorogenic acid profiles of English cider apples. Journal of the Science of Food and Agriculture, 87, 719-728. https:// doi.org/10.1002/jsfa.2778 
Mehrabani, L.V., Dadpour, M.R., Delazar, A., Movafeghi, A., Hassanpouraghdam, M.B. (2011). Quantification of phenolic compounds in peel and pupl of 'Zonouz' Apple cultivar from Iran. Romanian Biotechnological Letters, 16(4), 6390-6395.

Mehrabani, L.V., Hassanpouraghdam, M.B., Dadpour, M.R. (2012). HPLC assisted determination of phenolic compounds in two apple cultivars from Iran. Journal of Food, Agriculture \& Environment, 10(2), 233-235.

Mikulič Petkovšek, M., Štampar, F., Veberič, R. (2007). Parameters of inner quality of the scab resistant and susceptible apple in organic and integrated production. Scientia Horticulturae, 114, 37-44. https://doi.org/10.1016/j.scienta.2007.05.004

Mikulič Petkovšek, M., Štampar, F., Veberič, R. (2009). Changes in the inner quality parameters of apple fruit from technological to edible maturity. Acta Agriculturae Slovenica, 93(1), 17-29. https://doi.org/10.2478/v10014-009-0003-3

Mikulič Petkovšek, M., Slatnar, A., Štampar, F., Veberič, R. (2010). The influence of organic/integrated production on the content of phenolic compounds in apple leaves and fruits in four different varieties over a 2-year period. Journal of the Science of Food and Agriculture, 90, 2366-2378. https://doi.org/10.1002/jsfa.4093

Nicolas, J.J., Richard-Forget, F.C., Goupy, P.M., Amiot, M.J., Aubert, S.Y. (1994). Enzymatic browning reaction in apple and apple products. Critical Reviews in food Sciences and Nutrition, 34, 109-157. https://doi. org/10.1080/10408399409527653

Nogueira, A., Biscai, I., Wiecheteck, F.V.B., Denardi, F., Wosiacki, G. (2006). Physical chemical and technological evaluation of the juice of seven apple tree cultivars. Semina: Ciências Agrárias, 27, 89-98. https://doi.org/10.5433/16790359.2006v27n1p89

Paganini, C., Nogueira A., Denardi, F., Wosiacki, G. (2004). Industrial fitness analysis of six apple cultivars, considering their physico-chemical evaluation. Ciência e agrotecnologia., 28(6), 1336-1343. https://doi.org/10.1590/S141370542004000600016

Perez-Ilzarbe, J., Hernandez, T., Estella, I. (1991). Phenolic compounds in apples: varietal differences. Zeitschrift für Lebensmittel-Untersuchung und -Forschung, 192, 551-554. https://doi.org/10.1007/BF01202512

Reinders, R.D., Biesterveld, S., Bijker, P.G.H. (2001). Survival of E. coli O157:H7 ATCC 43895 in a model apple juice medium with different concentrations of proline and ceffeic acid. Applied and Environmental Microbiology, 67, 2863-2866. https://doi.org/10.1128/AEM.67.6.2863-2866.2001

Róth, E., Berna, A.Z., Beullens, K., Franck, C., Lammertyn, J., Schenk, A., Nicolai, B. (2005). A comparative study of quality attributes of integrated and organically produced apple fruit. Information and technology for sustainable fruit and vegetable production, Frutic 05, 12-16 September, Montpellier, France, 10 p.

Serra, A.T., Rocha, J., Sepodesa, B., Matias, A.A., Feliciano, R.P., Carvalho, A., Bronze, M.R., Duarte, C.M.M., Figueira, M.E. (2012). Evaluation of cardiovascular protective effect of different apple varieties- Correlation of response with composition. Food Chemistry, 135, 2378-2386. https://doi. org/10.1016/j.foodchem.2012.07.067

Sharma R. (2014). Polyphenols in health and disease: practice and mechanisms of benefits. Polyphenols in human health and disease, Academic, San Diegop. 757-778. https://doi. org/10.1016/B978-0-12-398456-2.00059-1

Shui, G., Leong, L.P. (2002). Separation and determination of organic acids and phenolic compounds in fruit juices and drinks by high-performance liquid chromatography.J. Chromatographia A, 977, 89-96. https://doi.org/10.1016/ S0021-9673(02)01345-6

Šturm, K., Štampar, F. (1999). Seasonal variation of sugars and organic acids in apple (Malus domestica Borkh.) in different growing systems. Phyton, 39(3), 91-96.

Sun, J., Chu, Y.F., Wu, X., Liu, R.H. (2002). Antioxidant and antiproliferative activities of common fruits. Journal of Agriculure and Food Chemistry, 50, 7449-7454. https://doi. org/10.1021/jf0207530

Thielen C., Will F., Zacharias J., Dietrich H., Jacob H. (2005). Distribution of dihydrochalcones and flavonols in apple tissue and comparison between fruit and juice. Proceeding of European Symppsoium on Apple Processing, 16-18 March 2005, Rennes, France, 68.

Tokuşoğlu, Ö. (2011). Bioactive phytochemicals in pome fruits. In: Fruit and cereal bioactives sources, chemistry and applications. Eds. Tokuşoğlu Ö., Hall C. CRC Press Taylor \& Francis Group, 107-119. https://doi.org/10.1201/b10786-8

Tsao, R., Yang, R., Young, J.C., Zhu, H. (2003). Polyphenolic profiles in eight apple cultivars using high-performance liquid chromatography (HPLC). Journal of Agriculure and Food Chemistry, 51, 6347-6353. https://doi.org/10.1021/ jf0346298

Valavanidis, A., Vlachogianni, T., Psomas, A., Zovoili, A., Siatis, V. (2009). Polyphenolic profile and antioxidant activity of five apple cultivars grown under organic and conventional agricultural practice. International Journal of Food Science \& Technology, 44, 1167-1175. https://doi.org/10.1111/ j.1365-2621.2009.01937.x

Veberič, R., Vodnik, D., Štampar, F. (2003). Carbon partitioning and seasonal dynamics of carbohydrates in the bark, leaves and fruits of apple (Malus domestica Borkh.) cv. 'Golden delicious'. European Journal of Horticultural Science, 68, 222-226.

Veberič, R., Trobec, M., Herbinger, K., Hofer, M., Grill, D., Štampar, F. (2005). Phenolic compounds in some apple (Malus domestica Borkh) cultivars of organic and integrated production. Journal of the Science of Food and Agriculture, 85, 1687-1694. https://doi.org/10.1002/jsfa.2113

Vieira, F.G.K., Borges, G.S.C., Copetti, C., Amboni, R.D.M.C., Denardi, F., Fett, R. (2009). Physico-chemical and antioxidant properties of six apple cultivars (Malus domestica Borkh.) grown in southern Brazil. Scientia Horticulturae, 122, 412-425. https://doi.org/10.1016/j.scienta.2009.06.012

Vieira, F.G.K., Borges, G.S.C., Copetti, C., Pietro, F.D., Nunes, E.C., Fett, R. (2011). Phenolic compounds and antioxidant activity of the apple flesh and peel of eleven cultivars grown in Brazil. Scientia Horticulturae, 128, 261-266. https://doi. org/10.1016/j.scienta.2011.01.032

Vranac, A., Begić-Akagić, A., Hudina, M., Oražem, P., Gaši, F., 
Spaho, N., Meland, M. (2014). Impact of cultivar and processing stage on the distribution of polyphenols in apples and their juices. Proceedings of $25^{\text {th }}$ International ScientificExpert Conference of Agriculture and Food Industry - Izmir 2014, Turkey, 165-168.

Vrhovšek, U., Rigo, A., Tonon, D., Mattivi, F. (2004). Quantification of Polyphenols in different apple varieties. Journal of Agriculure and Food Chemistry, 52, 6532-38. https://doi. org/10.1021/jf049317z

Wang, R., McCormick, R., Xuan, H., Streif, J. (2010). Distribution of sugar and organic acid components within the KOB heritage apple cultivar collection. Acta Horticulturae, 858, 89-97. https://doi.org/10.17660/ActaHortic.2010.858.10

Wojdyło, A., Oszmianski, J., Laskowski, P. (2008). Polyphenolic compounds and antioxidant activity of new and old apple varieties. Journal of Agriculure and Food Chemistry, 56, 6520-6530. https://doi.org/10.1021/jf800510j

Wolfe, K., Wu, X., Liu, R.H. (2003). Antioxidant activity of apple peels. Journal of Agriculure and Food Chemistry, 51, 609614. https://doi.org/10.1021/jf020782a

Wolfe, K., Liu, R.H. (2003). Apple peels as a value-added food ingredient. Journal of Agriculure and Food Chemistry, 51, 76-83. https://doi.org/10.1021/jf025916z

Wu J., Gao, H., Zhao, L., Liao, X., Chen, F., Wang, Z., Hu, Z. (2007). Chemical composition of some apple cultivars. Food Chemistry, 103, 88-93. https://doi.org/10.1016/j.foodchem.2006.07.030 